\title{
LOST REVENUES IN LOW INCOME COUNTRIES
}

Mark Curtis ${ }^{1}$ and Bernadette 0'Hare ${ }^{2}$

July 2017

\footnotetext{
${ }^{1}$ Director, Curtis Research, www.curtisresearch.org

${ }^{2}$ Senior Lecturer in Global Health, College of Medicine, University of Malawi and University of St Andrews, Scotland
} 


\section{INTRODUCTION}

This research estimates how much revenue six low income countries - of which five are in sub Saharan Africa - are losing unnecessarily from various potential revenue streams that could be used to fund public services.

In recent years, increased attention has been paid to government revenues lost to tax evasion and to tax incentives given to corporations. However, few attempts have been made to estimate losses for a larger number of potential revenue streams. This task is critical given the massive under-funding of public services, and the extent of need, in Low Income Countries.

Developing countries can lose revenue in a variety of ways. Here we estimate how much is being lost from the following sources:

- Corporate tax avoidance by multinational companies

- Providing tax incentives (for example, reductions or exemptions from the payment of corporate taxes) which constitute government 'tax expenditure'

- Not collecting taxes from a proportion of business activity in the informal sector

- Corruption in the national budget

- Debt interest payments to international creditors.

The responsibility for these revenue losses lies partly with foreign and partly with domestic actors. Multinational companies are depriving governments of revenues by failing to pay fair taxes. Many companies also receive tax incentives, which reduces their tax payments to governments still further. Governments could themselves be doing much more to stop the leakage of revenues. They could do much more to tax parts of the currently informal sector, which often comprise businesses operating under the radar of the tax authorities but which should pay their fair share of taxes. They must also do more to prevent corruption in the budget, which means that a proportion of public money allocated to support public services is often simply lost in the system somewhere. Both foreign and domestic actors need to ensure that low income countries are also paying back a fair proportion of the debt interest they owe, but no more than that.

\section{Note on methodology}

The research below attempts to provide the best available estimates for revenue losses from each of the potential resource streams for six countries and for SubSaharan Africa as a whole. This research can never be a scientific analysis: some figures are not available in some countries, others are by their nature somewhat speculative. Nevertheless, the figures provided indicate the scale of the problem and the scale of the potential for providing education and health for all. 
The research does not attempt to measure all outflows and all inflows to provide a balance sheet. The figures simply illustrate the problem of lost revenues from a variety of sources.

This research estimates are that governments could raise one half of potential revenues from the informal sector. It is not realistic or desirable to expect governments to tax all those currently operating informally: many people in the informal sector are extremely poor, such as small traders, for example, who should not be taxed.

Similarly, our estimates of lost revenues from debt interest payments are based on one half of the figure currently being paid by governments. This figure is loosely based on the estimation that some $60 \%$ of external borrowing from 1970 to 2004 by Africa left the continent the same year in the form of capital flight (illicit financial flows).

Other aspects of the methodology are explained in the country tables.

\section{Summary findings}

The research finds that revenue losses are large in all countries, which has significant implications for development. The priorities for low income countries are to end corporate tax avoidance, reduce corruption and raise tax collections. These areas are far more important than aid inflows.

- The six countries under analysis are losing $6.4 \%-12.9 \%$ of their GDP.

- In most cases, this amounts to more than the combined national health and education budgets, meaning that expenditure on these areas could more than double.

- Revenue losses are larger than aid in two of the six countries and over $60 \%$ of the amount of aid in a further three.

Our estimates use the African country figures to extrapolate a rough estimate for sub-Saharan Africa as a whole, which includes not only low income countries but also several lower middle income and upper middle income countries:

- When all these countries are included, we find that the continent may be losing around $\$ 182$ billion a year, four times larger than aid and greater than the continent's combined spending on health and education budgets.

The revenue losses are spread fairly evenly over four areas - the largest being from corruption and the informal sector followed by corporate tax avoidance and tax incentives. 
SUMMARY TABLES

Revenue losses by country

\begin{tabular}{|l|l|l|l|l|}
\hline Country & $\begin{array}{l}\text { Estimated } \\
\text { annual } \\
\text { revenue loss }\end{array}$ & $\begin{array}{l}\text { Revenue } \\
\text { loss per } \\
\text { capita }\end{array}$ & $\begin{array}{l}\text { Revenue loss } \\
\text { compared to } \\
\text { aid allocated } \\
\text { by donors }\end{array}$ & $\begin{array}{l}\text { Revenue loss compared to } \\
\text { government budgetary } \\
\text { allocation to health and } \\
\text { education sectors }\end{array}$ \\
\hline Malawi & $\begin{array}{l}\text { \$627 million } \\
(12.9 \% \text { of GDP })\end{array}$ & $\$ 38$ & $63 \%$ & $\begin{array}{l}\text { Nearly twice the combined } \\
\text { education and health budget }\end{array}$ \\
\hline Mozambique & $\begin{array}{l}\text { \$1.75 billion } \\
(11.4 \% \text { of GDP })\end{array}$ & $\$ 66$ & $97 \%$ & $\begin{array}{l}\text { Same as the combined } \\
\text { education and health budget }\end{array}$ \\
\hline Nepal & $\begin{array}{l}\text { \$1.87 billion } \\
(7.4 \% \text { of GDP })\end{array}$ & $\$ 67$ & Over $100 \%$ & $\begin{array}{l}\text { Nearly double the combined } \\
\text { education and health budget }\end{array}$ \\
\hline Sierra Leone & $\begin{array}{l}\$ 265 \text { million } \\
(6.4 \% \text { of GDP })\end{array}$ & $\$ 43$ & $28 \%$ & $\begin{array}{l}\text { Nearly double the combined } \\
\text { education and health budget }\end{array}$ \\
\hline Tanzania & $\begin{array}{l}\text { \$4.53 billion } \\
(9.4 \% \text { of GDP })\end{array}$ & $\$ 90$ & Over $100 \%$ & $\begin{array}{l}\text { More than the combined } \\
\text { health and education budget }\end{array}$ \\
\hline Uganda & $\begin{array}{l}\text { \$1.9 billion } \\
(7.7 \% \text { of GDP })\end{array}$ & $\$ 52$ & $84 \%$ & $\begin{array}{l}\text { More than the combined } \\
\text { health and education budget }\end{array}$ \\
\hline & & & & Over $400 \%$ \\
\hline $\begin{array}{l}\text { Sub-Saharan } \\
\text { Africa }\end{array}$ & $\begin{array}{l}\text { \$182 billion } \\
(11.4 \% \text { of GDP })\end{array}$ & $\$ 182$ & $\begin{array}{l}\text { More than combined health } \\
\text { and education budgets }\end{array}$ \\
\hline
\end{tabular}

Revenue losses by type of resource (\$ million)

\begin{tabular}{|l|l|l|l|l|l|}
\hline & $\begin{array}{l}\text { Tax avoidance } \\
\text { by } \\
\text { multinational } \\
\text { companies }\end{array}$ & $\begin{array}{l}\text { Informal } \\
\text { sector }\end{array}$ & $\begin{array}{l}\text { Tax } \\
\text { incentives }\end{array}$ & Corruption & $\begin{array}{l}\text { Debt } \\
\text { payments }\end{array}$ \\
\hline Malawi & 86 & 190 & 100 & 243 & 8 \\
\hline Mozambique & 457 & 412 & 325 & 459 & 95 \\
\hline Nepal & 145 & 448 & 1,260 & No estimate & 32 \\
\hline Sierra Leone & 108 & 87.5 & 3.5 & 62 & 3.7 \\
\hline Tanzania & 748 & 2,020 & 429 & 1,300 & 49 \\
\hline Uganda & 529 & 625 & 248 & 500 & 21 \\
\hline & & & & & 14,400 \\
\hline $\begin{array}{l}\text { Sub-Saharan } \\
\text { Africa }\end{array}$ & 34,800 & 49,000 & 31,800 & 51,500 & \\
\hline
\end{tabular}




\section{Lost revenue per capita}

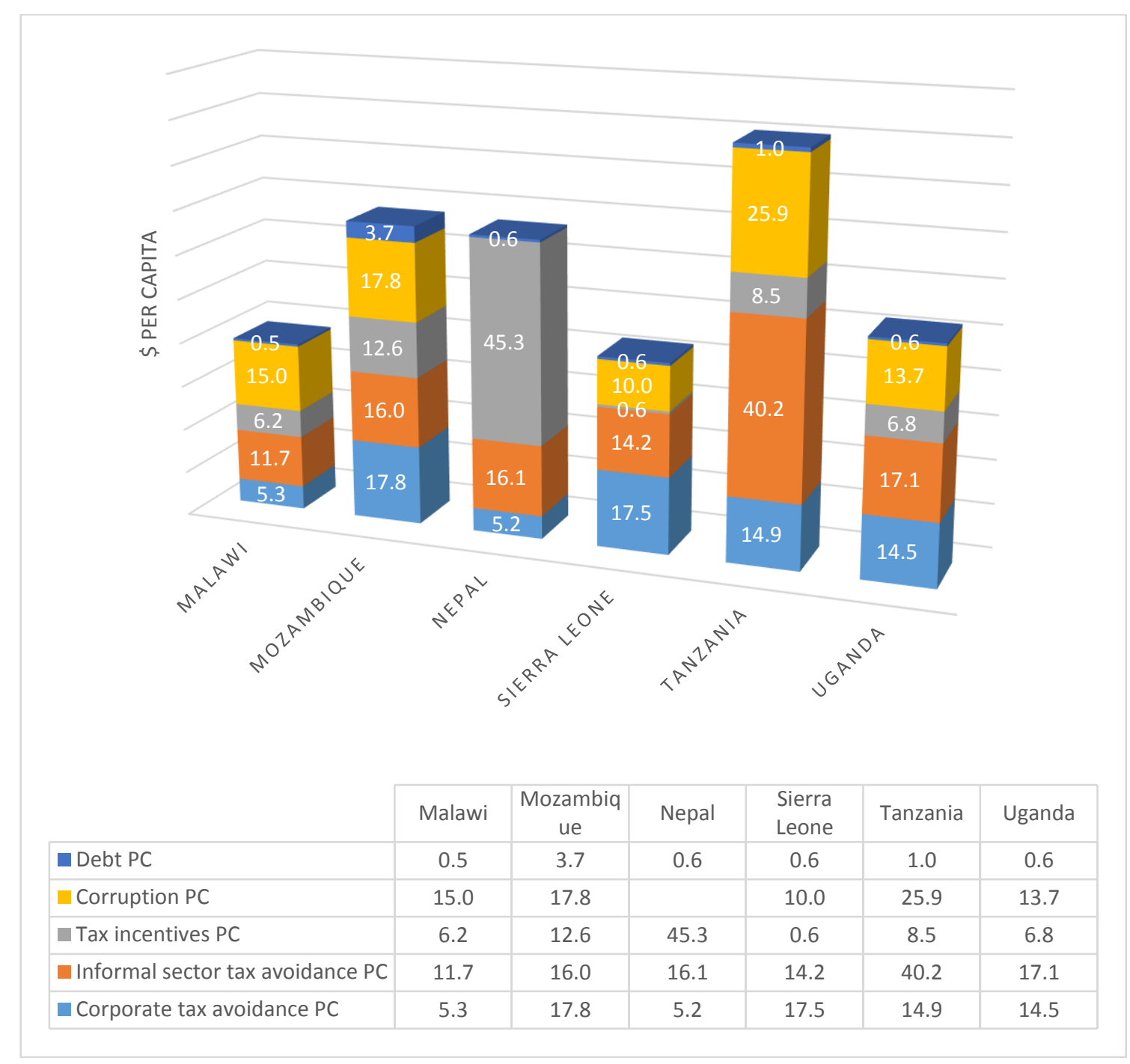

\section{Implications of this analysis}

This analysis shows that low income countries have significant potential revenues streams available to them and that they are likely to be able to double their spending on health and education if lost revenues could be curbed. The key priorities are to raise more taxes from the informal sector, by reforming tax administrations, take steps to curtail corruption, especially in the government budget, and eradicate harmful tax incentives. All these areas are within governments' competence and control.

Low income governments and advocates must also press international actors to halt corporate tax avoidance and Northern states must seriously act to prevent multinational companies under their jurisdiction from depriving countries of revenues. 
The figures suggest that high income governments also need to re-evaluate the role and purpose of aid in light of the availability of domestic revenues. Aid is often marginal or small compared to revenue losses and should be reconfigured to support low income countries' ability to raise more domestic revenues, such as by aiding reform of their tax administrations.

Individuals and organisations committed to social justice must individually and collectively divest from, and shun, multinationals which engage in irresponsible tax practices in low income countries. Such companies should be categorized as unethical, similar to fossil fuels, tobacco and the arms trade by fund managers which offer ethical alternatives to customers. 


\title{
COUNTRY DATA
}

\author{
MALAWI
}

\section{Summary}

- Malawi is likely to be losing around $\$ 627$ million a year - equivalent to $12.9 \%$ of its GDP 1 - in revenues from different sources.

- Revenue losses amount to over $60 \%$ of the aid allocated to Malawi by donors.

- This $\$ 627$ million resource loss is nearly twice the combined education and health budget.

\section{Malawi's revenue losses}

\begin{tabular}{|c|c|c|}
\hline Issue & $\begin{array}{l}\text { Annual } \\
\text { revenue loss }\end{array}$ & Comment \\
\hline $\begin{array}{l}\text { Tax avoidance } \\
\text { by } \\
\text { multinational } \\
\text { companies }\end{array}$ & $\$ 86 \mathrm{~m}$ & This figure is calculated by Cobham/Jansky in recent research. ${ }^{2}$ \\
\hline $\begin{array}{l}\text { Informal } \\
\text { sector }\end{array}$ & $\$ 190 \mathrm{~m}$ & $\begin{array}{l}\text { The size of Malawi's informal sector (shadow economy) was } \\
\text { estimated by the Tax Justice Network at } 41.8 \% \text { of GDP in } \\
2011 .{ }^{3} \text { Using this figure, and the same method of calculating lost tax } \\
\text { revenues as a result, produces a figure of } \$ 380 \text { million. }{ }^{4} \text { However, } \\
\text { many activities in the informal economy are carried out by } \\
\text { extremely poor people who, it can be argued, should not be taxed. It } \\
\text { is not possible to provide a precise estimate of the legitimate } \\
\text { proportion of this lost income that should be gained by the state - } \\
\text { we simply estimate one half (one half of } \$ 380 \text { million is } \$ 190 \\
\text { million) }\end{array}$ \\
\hline Tax incentives & $\$ 100 \mathrm{~m}$ & $\begin{array}{l}\text { This is an estimate based on past independent research. The } \\
\text { government does not publish a figure for its tax expenditure. } \\
\text { Thomas Munthali, a former president of the Economics Association } \\
\text { of Malawi, estimated in } 2015 \text { that Malawi was foregoing } \$ 100 \\
\text { million/MK } 47 \text { billion a year in tax incentives. } \\
\text { A } 2012 \text { report for the Malawi Economic Justice Network estimated } \\
\text { that Malawi lost MK } 100.1 \text { billion in the } 5 \text { years } 2008-12-\text { an } \\
\text { average of MK } 20.02 \text { billion a year. } 6 \text { This involved } \\
\text { exemptions/incentives granted to companies and was derived by } \\
\text { looking through a sample of company accounts. At a rough average } \\
\text { exchange rate for the years } 2008-12^{7}, \text { MK } 100.1 \text { billion converts to } \\
\$ 588 \text { million in the five years meaning an average of } \$ 117.6 \text { million }\end{array}$ \\
\hline
\end{tabular}




\begin{tabular}{|c|c|c|}
\hline & & a year. \\
\hline Corruption & $\$ 243 m$ & $\begin{array}{l}\text { By definition, an accurate figure for revenue losses from corruption } \\
\text { is not obtainable. A detailed } 2011 \text { analysis by the World Bank } \\
\text { estimated that corruption amounted to } 5 \% \text { of GDP, in addition to the } \\
\text { tax fraud of } 8-12 \% \text { of GDP. } \text { This estimate uses the } 5 \% \text { figure. }^{8} \text { Malawi's GDP in } 2014 / 15 \text { was MK } 2,848 \text { billion. }{ }^{9} \text { Thus } 5 \% \text { is MK } 142 \\
\text { billion, equivalent to } \$ 243 \text { million. }{ }^{10}\end{array}$ \\
\hline $\begin{array}{l}\text { Debt } \\
\text { payments }\end{array}$ & $\$ 8 m$ & $\begin{array}{l}\text { The figure is for } 50 \% \text { of Malawi's interest payments on external debt } \\
\text { in } 2015 \text {, according to the World Bank. } 11 \text { This is a rough estimation of } \\
\text { 'odious debts'; the figure of } 50 \% \text { is loosely based on the estimation } \\
\text { that some } 60 \% \text { of external borrowing between } 1970-2004 \text { by Africa } \\
\text { left the continent the same year in the form of capital flight (Illicit } \\
\text { Financial Flows). }{ }^{2}\end{array}$ \\
\hline TOTAL LOSS & $627 \mathrm{~m}$ & \\
\hline $\begin{array}{l}\text { Revenue loss } \\
\text { per capita }\end{array}$ & $\$ 38$ & \\
\hline
\end{tabular}

\section{NB. IMF estimate of Malawi's 'tax gap'}

A detailed analysis by the World Bank in 2011 estimated that tax fraud alone in Malawi (mainly evasion of VAT, corporate taxes, and import/export duties by trade mispricing) amounted to $8-12 \%$ of GDP. ${ }^{14}$ Using the middle figure $(10 \%$ of GDP), Malawi would then have been losing around MK 285 billion ( $\$ 487$ million). ${ }^{15}$ The study noted that if the national tax authority had collected all the taxes it was due, government revenue would increase by $50 \%$, which was approximately how much Malawi then received in foreign aid (11.7\% of GDP). ${ }^{16}$

\section{Aid}

Malawi was allocated $\$ 1.0$ billion in aid by donors in $2015 .{ }^{17}$

\section{What could the lost resources fund in health and education?}

In the government's 2016/7 budget, MK 95.8 billion is allocated to health and MK 147.6 billion is allocated to education. ${ }^{18}$ These convert to $\$ 132$ million and $\$ 204$ million, respectively. ${ }^{19}$ This $\$ 627$ million resource loss is nearly twice the combined education and health budget. 


\section{MOZAMBIQUE}

\section{Summary}

- Mozambique is losing an estimated $\$ 1.75$ billion - equivalent to $11.4 \%$ of its GDP - in revenues from different sources.

- This revenue loss is very nearly as much as aid allocated to Mozambique by donors ( $\$ 1.8$ billion)

- This revenue loss amounts to the same as the government's combined education and health spending.

\section{Mozambique's revenue losses}

\begin{tabular}{|c|c|c|}
\hline Issue & $\begin{array}{l}\text { Annual } \\
\text { revenue } \\
\text { loss } \\
\end{array}$ & Comment \\
\hline $\begin{array}{l}\text { Tax } \\
\text { avoidance by } \\
\text { multinational } \\
\text { companies }\end{array}$ & $\$ 457 \mathrm{~m}$ & This figure is calculated by Cobham/Jansky in recent research. ${ }^{20}$ \\
\hline $\begin{array}{l}\text { Informal } \\
\text { sector }\end{array}$ & $\$ 412 \mathrm{~m}$ & $\begin{array}{l}\text { Estimating the size of the informal sector is difficult. The Ministry } \\
\text { of Planning and Development estimates using national accounts } \\
\text { data suggest that informal activity represented } 40 \% \text { of GDP in } \\
2004 .^{21} \text { Using this figure, and the same method of calculating lost } \\
\text { tax revenues as a result, produces a figure of } \$ 824 \text { million. }{ }^{22} \\
\text { However, many activities in the informal economy are carried out } \\
\text { by extremely poor people who, it can be argued, should not be } \\
\text { taxed. It is not possible to provide a precise estimate of the } \\
\text { legitimate proportion of this lost income that should be gained by } \\
\text { the state - we simply estimate one half (one half of } \$ 824 \text { million is } \\
\$ 412 \text { million) }\end{array}$ \\
\hline $\begin{array}{l}\text { Tax } \\
\text { incentives }\end{array}$ & $\$ 325 \mathrm{~m}$ & $\begin{array}{l}\text { A } 2016 \text { IMF report gives figures on Mozambique's overall tax } \\
\text { expenditure. It states that this was } 4 \% \text { of GDP in } 2013 \text { and } 3.3 \% \\
\text { in } 2014 .^{23} \text { The report does not give amounts in meticais or dollars } \\
\text { but using another IMF report these revenue losses would amount } \\
\text { to around MT } 19.3 \text { billion / } \$ 640 \text { million in } 2013 \text { and MT } 17.6 \\
\text { billion / } \$ 561 \text { million in } 2014 .^{24} \\
\text { The IMF report does not state what proportion of the revenue } \\
\text { losses derive from corporations. But a } 2009 \text { report for USAID } \\
\text { provided figures on revenue losses from corporate income tax } \\
\text { incentives. These amounted to MT } 3.97 \text { billion (out of total tax } \\
\text { exemptions of MT } 6.86 \text { billion) in } 2007 \text { - thus } 58 \% \text { of all tax } \\
\text { incentives. } 25 \text { We use this figure of } 58 \% \text { of the } 2016 \text { figure for all }\end{array}$ \\
\hline
\end{tabular}




\begin{tabular}{|c|c|c|}
\hline & & $\begin{array}{l}\text { incentives (MT } 17.6 \text { billion/ } \$ 561 \text { million in } 2014 \text { ) to arrive at an } \\
\text { estimate of } \$ 325 \text { million. } \\
\text { One study has noted that Mozambique's tax gap for VAT } \\
\text { collections alone is 5.5\% of GDP26, which would amount to } \\
\text { around } \$ 842 \text { million (to } \$ 15.3 \text { billion). }{ }^{27}\end{array}$ \\
\hline Corruption & $\$ 459 m$ & $\begin{array}{l}\text { A } 2016 \text { study estimated that revenue losses from corruption } \\
\text { during } 2004-2014 \text { amounted to between } \$ 1.8 \text { billion and } \$ 4.9 \\
\text { billion (the latter figure being average of around } 4 \% \text { of GDP.28) } \\
\text { The middle figure ( } \$ 3.35 \text { billion in total or an average of } \$ 335 \\
\text { million a year) may be around 3\% of GDP a year on average. } \\
\text { Based on Mozambique's GDP in } 2015 \text { of MT } 598 \text { billion }{ }^{29} \\
\text { equivalent to } \$ 15.3 \text { billion }{ }^{30}, 3 \% \text { would amount to } \$ 459 \text { million. } \\
\text { In the above-noted report, corruption practices in customs were } \\
\text { identified as the main site of corruption, involving bribery and } \\
\text { non-payment of fees on imports. Other sites of corruption were } \\
\text { State-owned Enterprises (SOEs), private companies owned by } \\
\text { state institutions and Public-private partnerships. }{ }^{31}\end{array}$ \\
\hline $\begin{array}{l}\text { Debt } \\
\text { payments }\end{array}$ & $\$ 95 \mathrm{~m}$ & $\begin{array}{l}\text { The figure is for } 50 \% \text { of Mozambique's interest payments on } \\
\text { external debt in } 2015 \text {, according to the World Bank. }{ }^{32} \text { This is a } \\
\text { rough estimation of 'odious debts'; the figure of } 50 \% \text { is loosely } \\
\text { based on the estimation that some } 60 \% \text { of external borrowing } \\
\text { between } 1970-2004 \text { by Africa left the continent the same year in } \\
\text { the form of capital flight (Illicit Financial Flows). } .^{33}\end{array}$ \\
\hline TOTAL LOSS & $\$ 1.75 b$ & \\
\hline $\begin{array}{l}\text { Revenue loss } \\
\text { per capita }^{34}\end{array}$ & $\$ 66$ & \\
\hline
\end{tabular}

Aid

Mozambique was allocated $\$ 1.8$ billion in aid by donors in $2015 .{ }^{35}$

What could the lost resources fund in health and education?

In 2016, the government budget allocated MT 54.4 billion ( $\$ 1.2$ billion) to education and MT 25.6 billion ( $\$ 578$ million) to health. ${ }^{36}$ Thus the loss of $\$ 1.75$ billion could more than double the combined health and education budget. 


\section{NEPAL}

\section{Summary}

- Nepal is likely to be losing around $\$ 1.87$ billion a year - equivalent to around $7.4 \%$ of its GDP - in revenues from different sources.

- This revenue loss amounts to much more than the amount of aid allocated to Nepal by donors.

- The lost revenues could more than double the combined education and health budgets.

\section{Nepal's revenue losses}

\begin{tabular}{|c|c|c|}
\hline Issue & $\begin{array}{l}\text { Annual } \\
\text { revenue } \\
\text { loss }\end{array}$ & Comment \\
\hline $\begin{array}{l}\text { Tax } \\
\text { avoidance by } \\
\text { multinational } \\
\text { companies }\end{array}$ & $\$ 145 \mathrm{~m}$ & This figure is calculated by Cobham/Jansky in recent research. ${ }^{37}$ \\
\hline $\begin{array}{l}\text { Informal } \\
\text { sector }\end{array}$ & $\$ 448 \mathrm{~m}$ & $\begin{array}{l}\text { The size of Nepal's informal sector (shadow economy) was } \\
\text { estimated by the Tax Justice Network at } 36.7 \% \text { of GDP in } 2011 .{ }^{38} \\
\text { Using this figure, and the same method of calculating lost tax } \\
\text { revenues as a result, produces a figure of Rs } 96.2 \text { billion ( } \$ 895 \\
\text { million). }{ }^{39} \text { However, many activities in the informal economy are } \\
\text { carried out by extremely poor people who, it can be argued, } \\
\text { should not be taxed. It is not possible to provide a precise } \\
\text { estimate of the legitimate proportion of this lost income that } \\
\text { should be gained by the state - we simply estimate one half: thus } \\
\text { Rs } 48 \text { billion ( } \$ 448 \text { million). }\end{array}$ \\
\hline $\begin{array}{l}\text { Tax } \\
\text { incentives }\end{array}$ & $\$ 1.26$ billion & Around $5 \%$ of GDP 40 - around Rs 136 billion ( $\$ 1.26$ billion). ${ }^{41}$ \\
\hline Corruption & Unknown & $\begin{array}{l}\text { Corruption is reported to be significant in } \mathrm{Nepal}^{42} \text { (although less } \\
\text { extensive than in neighbouring countries }{ }^{43} \text { ) but there are no } \\
\text { precise estimates available. }\end{array}$ \\
\hline $\begin{array}{l}\text { Debt } \\
\text { payments }\end{array}$ & $\$ 16 m$ & $\begin{array}{l}\text { The figure is for } 50 \% \text { of Nepal's interest payments on external } \\
\text { debt in } 2015 \text {, according to the World Bank. }{ }^{44} \text { This is a rough } \\
\text { estimation of 'odious debts'; the figure of } 50 \% \text { is loosely based on } \\
\text { the estimation that some } 60 \% \text { of external borrowing between } \\
1970-2004 \text { by Africa left the continent the same year in the form } \\
\text { of capital flight (Illicit Financial Flows). }{ }^{45}\end{array}$ \\
\hline TOTAL LOSS & $\$ 1.87 b$ & \\
\hline $\begin{array}{l}\text { Revenue loss } \\
\text { per capita }^{46}\end{array}$ & $\$ 67$ & \\
\hline
\end{tabular}


Aid

Nepal was allocated $\$ 1.2$ billion in aid by donors in 2015.47

\section{What could the lost resources fund in health and education?}

In the $2016 / 77$ budget, the government allocated Rs 115.8 billion ( $\$ 1.07$ billion) to education and Rs 48.4 billion ( $\$ 447$ million) to health. ${ }^{48}$ Thus the lost revenues could more than double the combined education and health budgets. 


\section{SIERRA LEONE}

\section{Summary}

- Sierra Leone is likely to be losing $\$ 265$ million a year - equivalent to around $6.4 \%$ of its GDP - in revenues from different sources.

- This revenue loss amounts to over a quarter of the amount of aid allocated to Sierra Leone by donors.

- This loss is nearly double combined government health and education spending.

\section{Sierra Leone's revenue losses}

\begin{tabular}{|c|c|c|}
\hline Issue & $\begin{array}{l}\text { Annual } \\
\text { revenue } \\
\text { loss }\end{array}$ & Comment \\
\hline $\begin{array}{l}\text { Corporate tax } \\
\text { avoidance by } \\
\text { multinational } \\
\text { companies }\end{array}$ & $\$ 108 \mathrm{~m}$ & This figure is calculated by Cobham/Jansky in recent research. ${ }^{49}$ \\
\hline $\begin{array}{l}\text { Informal } \\
\text { sector }\end{array}$ & $\$ 87.5 \mathrm{~m}$ & $\begin{array}{l}\text { The size of Sierra Leone's informal sector (shadow economy) was } \\
\text { estimated by the Tax Justice Network at } 45.6 \% \text { of GDP in } 2011 .{ }^{50} \\
\text { Using this figure, and the same method of calculating lost tax } \\
\text { revenues as a result, produces a figure of } \$ 175 \text { million. }{ }^{51} \\
\text { However, many activities in the informal economy are carried out } \\
\text { by extremely poor people who, it can be argued, should not be } \\
\text { taxed. It is not possible to provide a precise estimate of the } \\
\text { legitimate proportion of this lost income that should be gained by } \\
\text { the state - we simply estimate one half (thus } \$ 87.5 \text { million) }\end{array}$ \\
\hline $\begin{array}{l}\text { Tax } \\
\text { incentives }\end{array}$ & $\$ 3.5 \mathrm{~m}$ & $\begin{array}{l}\text { The IMF and government estimate these in } 2016 \text { at } 0.1 \% \text { of GDP / } \\
\text { Le } 25 \text { billion ( } \$ 3.5 \text { million). }{ }^{2} \\
\text { In the recent past, Sierra Leone lost very large amounts of } \\
\text { revenue from tax incentives. One estimate is that these losses } \\
\text { were over } \$ 200 \text { million a year in } 2011 \text { and } 2012 \text {, a period of large } \\
\text { mining investment. }{ }^{53} \text { Since then, however, some key large-scale } \\
\text { mining projects have undergone substantial change and the } \\
\text { government has been reducing exemptions/incentives }\end{array}$ \\
\hline Corruption & $\$ 62 \mathrm{~m}$ & $\begin{array}{l}\text { Corruption is reported to be very extensive in Sierra Leone }{ }^{54} \text { but } \\
\text { no figures or reliable estimates are available on the amount of } \\
\text { revenues lost to corruption. We take a very conservative estimate } \\
\text { - that } 10 \% \text { of government expenditure is lost to corruption, } \\
\text { which amounts to around } \$ 62 \text { million. }{ }^{55}\end{array}$ \\
\hline
\end{tabular}




\begin{tabular}{|c|c|c|}
\hline $\begin{array}{l}\text { Debt } \\
\text { payments }\end{array}$ & $\$ 3.7 \mathrm{~m}$ & $\begin{array}{l}\text { The figure is for } 50 \% \text { of Sierra Leone's interest payments on } \\
\text { external debt in } 2015 \text {, according to the World Bank. }{ }^{56} \text { This is a } \\
\text { rough estimation of 'odious debts'; the figure of } 50 \% \text { is loosely } \\
\text { based on the estimation that some } 60 \% \text { of external borrowing } \\
\text { between } 1970-2004 \text { by Africa left the continent the same year in } \\
\text { the form of capital flight (Illicit Financial Flows). }{ }^{57}\end{array}$ \\
\hline TOTAL LOSS & $\$ 265 \mathrm{~m}$ & \\
\hline $\begin{array}{l}\text { Revenue loss } \\
\text { per capita }^{58}\end{array}$ & $\$ 43$ & \\
\hline
\end{tabular}

\section{IMF estimate of Sierra Leone's 'tax gap'}

The IMF notes that Sierra Leone's GDP could increase by $1.0 \%$ by efficiency gains in the National Revenue Authority, by reducing exemptions and combatting fraud. ${ }^{59}$ This amounts to around Le 267 billion ( $\$ 36.0$ million). ${ }^{60}$

\section{Aid}

Sierra Leone was allocated $\$ 946$ million in aid by donors in $2015 .{ }^{61}$

\section{What could the lost resources fund in health and education?}

In the 2017 budget, the government allocated around Le 274 billion ( $\$ 37$ million) to the health sector was allocated and Le 794 billion ( $\$ 107$ million) to education. ${ }^{62}$ The revenue loss figure ( $\$ 265$ million) is therefore nearly double combined health and education spending. 


\section{TANZANIA}

\section{Summary}

- Tanzania is likely to be losing as much as $\$ 4.53$ billion a year - equivalent to $9.4 \%$ of its GDP - in revenues from different sources.

- This revenue loss amounts to much more than the amount of aid allocated to Tanzania by donors.

- Revenue losses amount to well over combined health and education spending.

\section{Tanzania's revenue losses}

\begin{tabular}{|c|c|c|}
\hline Issue & $\begin{array}{l}\text { Annual } \\
\text { revenue } \\
\text { loss }\end{array}$ & Comment \\
\hline $\begin{array}{l}\text { Corporate tax } \\
\text { avoidance by } \\
\text { multinational } \\
\text { companies }\end{array}$ & $\$ 748 m$ & This figure is calculated by Cobham/Jansky in recent research. ${ }^{63}$ \\
\hline $\begin{array}{l}\text { Informal } \\
\text { sector }\end{array}$ & $\$ 2.0 \mathrm{~b}$ & $\begin{array}{l}\text { The size of Tanzania's informal sector (shadow economy) was } \\
\text { estimated by the Tax Justice Network at } 56.4 \% \text { of GDP in } 2011.64 \\
\text { Using this figure, and the same method of calculating lost tax } \\
\text { revenues as a result, produces a figure of } \$ 4.04 \text { billion. }{ }^{65} \\
\text { However, many activities in the informal economy are carried out } \\
\text { by extremely poor people who, it can be argued, should not be } \\
\text { taxed. It is not possible to provide a precise estimate of the } \\
\text { legitimate proportion of this lost income that should be gained by } \\
\text { the state - we simply estimate one half (thus } \$ 2.0 \text { billion). }{ }^{66}\end{array}$ \\
\hline $\begin{array}{l}\text { Tax } \\
\text { incentives }\end{array}$ & $\$ 429 m$ & $\begin{array}{l}\text { The latest figure available is TShs } 927 \text { billion }^{67}\left(\$ 429 \text { million }^{68}\right) \\
\text { although this covers only import duty and VAT exemptions and } \\
\text { not tax incentives on, for example, corporate income. }\end{array}$ \\
\hline Corruption & $\$ 1.3 \mathrm{~b}$ & $\begin{array}{l}\text { Government officials estimate that each fiscal year, corruption is } \\
\text { responsible for a } 20 \% \text { loss from the government's budget.69 In } \\
2016 / 17 \text { government expenditure was slated to amount to TShs } \\
29.5 \text { trillion }{ }^{70} \text {; of which } 20 \% \text { is TShs } 2.9 \text { trillion ( } \$ 1.3 \text { billion). }\end{array}$ \\
\hline $\begin{array}{l}\text { Debt } \\
\text { payments }\end{array}$ & $\$ 49 m$ & $\begin{array}{l}\text { The figure is for } 50 \% \text { of Tanzania's interest payments on external } \\
\text { debt in } 2015 \text {, according to the World Bank. }{ }^{71} \text { This is a rough } \\
\text { estimation of 'odious debts'; the figure of } 50 \% \text { is loosely based on } \\
\text { the estimation that some } 60 \% \text { of external borrowing between } \\
1970-2004 \text { by Africa left the continent the same year in the form } \\
\text { of capital flight (Illicit Financial Flows). } .^{2}\end{array}$ \\
\hline TOTAL LOSS & $\$ 4.53 b$ & \\
\hline $\begin{array}{l}\text { Revenue loss } \\
\text { per capita }^{73}\end{array}$ & $\$ 90$ & \\
\hline
\end{tabular}




\section{NB. IMF estimate of Tanzania's 'tax gap'}

The IMF calculates that the tax revenue gap in Tanzania - resulting from tax administration inefficiencies, tax evasion and tax policy design - was $4.3 \%$ of GDP in 2009-13 and is around $2.2-2.8 \%$ presently. ${ }^{74}$ The IMF estimates Tanzania's tax capacity as $15.2-15.8 \%$ of GDP - meaning that anything short of this is lost revenues. ${ }^{75}$ This puts Tanzania's tax gap, as defined by the IMF, at around $\$ 1.21$ billion (TShs 2.7 trillion) in 2016/17.76

\section{Aid}

Tanzania was allocated $\$ 2.6$ billion in aid by donors in $2015 .{ }^{77}$

\section{What could the lost resources fund in health and education?}

In the 2016/17 budget, health was allocated TShs 2.0 trillion ( $\$ 895$ million) and education TShs 4.8 trillion ( $\$ 2.15$ billion). ${ }^{78}$ Thus revenue losses amount to much more than combined health and education spending. 


\section{UGANDA}

\section{Summary}

- Uganda is likely to be losing around $\$ 1.9$ billion a year - equivalent to around $7.7 \%$ of its GDP - in revenues from different sources.

- This revenue loss amounts to over $80 \%$ of the amount of aid to Uganda allocated by donors.

- This revenue loss is much greater than combined health and education spending.

\section{Uganda's revenue losses}

\begin{tabular}{|c|c|c|}
\hline Issue & $\begin{array}{l}\text { Annual } \\
\text { revenue } \\
\text { loss }\end{array}$ & Comment \\
\hline $\begin{array}{l}\text { Tax } \\
\text { avoidance by } \\
\text { multinational } \\
\text { companies }\end{array}$ & $\$ 529 \mathrm{~m}$ & This figure is calculated by Cobham/Jansky in recent research. ${ }^{79}$ \\
\hline $\begin{array}{l}\text { Informal } \\
\text { sector }\end{array}$ & $\$ 625 \mathrm{~m}$ & $\begin{array}{l}\text { The size of Uganda's informal sector (shadow economy) was } \\
\text { estimated by the Tax Justice Network at } 42.3 \% \text { of GDP in } 2011 .{ }^{80} \\
\text { Using this figure, and the same method of calculating lost tax } \\
\text { revenues as a result, produces a figure of } \$ 1.25 \text { billion. }{ }^{81} \\
\text { However, many activities in the informal economy are carried out } \\
\text { by extremely poor people who, it can be argued, should not be } \\
\text { taxed. It is not possible to provide a precise estimate of the } \\
\text { legitimate proportion of this lost income that should be gained by } \\
\text { the state - we simply estimate one half (thus UShs } 2.2 \text { trillion or } \\
\$ 625 \text { million) }\end{array}$ \\
\hline $\begin{array}{l}\text { Tax } \\
\text { incentives }\end{array}$ & $\$ 248 \mathrm{~m}$ & $\begin{array}{l}\text { We estimate a very conservative figure equivalent to } 1.0 \% \text { of } \\
\text { GDP. }{ }^{82} \text { It remains unclear how much Uganda is losing to tax } \\
\text { incentives since the government does not provide full figures. A } \\
2012 \text { report cited African Development Bank estimates that } \\
\text { Uganda's losses from tax incentives were 'at least } 2 \% \text { ' of GDP. } 83 \\
\text { This would amount to around UShs } 690 \text { billion ( } \$ 272 \text { million) in } \\
2009 / 10 .^{84} \mathrm{~A} \text { new, even higher figure was reported in the media in } \\
2013, \text { saying that a Uganda Revenue Authority audit for } \\
2010 / 2011 \text { reported losses of up to UShs } 850 \text { billion ( } \$ 370 \\
\text { million }{ }^{85} \text { ) in tax waivers and exemptions. }{ }^{86} \text { Since then, the } \\
\text { government has taken significant steps to reduce VAT and some } \\
\text { other exemptions. However, many incentives for corporations } \\
\text { remain, notably for oil companies, which continue to result in } \\
\text { large revenue losses. }{ }^{87}\end{array}$ \\
\hline
\end{tabular}




\begin{tabular}{|c|c|c|}
\hline Corruption & $\$ 500 \mathrm{~m}$ & $\begin{array}{l}\text { Corruption is reported to be widespread in Uganda } 88 \text { but no } \\
\text { figures or reliable estimates are available on the amount of } \\
\text { revenues lost to corruption. We have conservatively estimated } \\
\text { the figure at } \$ 500 \text { million. In } 2005 \text {, the World Bank estimated that } \\
\text { Uganda was losing about } \$ 300 \text { million (UShs } 900 \text { billion) through } \\
\text { corruption and procurement malpractice every year. Recently, } \\
\text { the Anti-Corruption Coalition Uganda has said that this might } \\
\text { have doubled by now since the government has taken 'no serious } \\
\text { step to curb corruption'. } 89\end{array}$ \\
\hline $\begin{array}{l}\text { Debt } \\
\text { payments }\end{array}$ & $\$ 21 \mathrm{~m}$ & $\begin{array}{l}\text { The figure is for } 50 \% \text { of Uganda's interest payments on external } \\
\text { debt in } 2015 \text {, according to the World Bank. } .0 \text { This is a rough } \\
\text { estimation of 'odious debts'; the figure of } 50 \% \text { is loosely based on } \\
\text { the estimation that some } 60 \% \text { of external borrowing between } \\
1970-2004 \text { by Africa left the continent the same year in the form } \\
\text { of capital flight (Illicit Financial Flows). } .^{91}\end{array}$ \\
\hline TOTAL & $\$ 1.9 b$ & \\
\hline $\begin{array}{l}\text { Revenue loss } \\
\text { per capita92 }^{92}\end{array}$ & $\$ 52$ & \\
\hline
\end{tabular}

\section{Aid}

Uganda was allocated $\$ 1.6$ billion in aid by donors in 2015.93

\section{What could the lost resources fund in health and education?}

In the 2016/77 budget, the government allocated UShs 1.83 trillion ( $\$ 510$ million) to the health sector and UShs 2.45 trillion ( $\$ 683$ million) to education. ${ }^{94}$ Uganda's revenue losses could more than double this combined spending on health and education. 


\section{SUB-SAHARAN AFRICA}

The research has taken the figures for the five Sub-Saharan African countries to extrapolate figures for across the continent.

\section{Summary}

- Sub-Saharan Africa is likely losing around $\$ 182$ billion a year, equivalent to $11.4 \%$ of its GDP, in revenues from different sources.

- This revenue loss amounts to over four times the amount of aid allocated to Sub-Saharan Africa by donors

- The lost revenues could double combined health and education spending in Sub-Saharan Africa.

\section{Sub-Saharan Africa's revenue losses}

\begin{tabular}{|c|c|c|}
\hline Issue & $\begin{array}{l}\text { Annual } \\
\text { revenue } \\
\text { loss }\end{array}$ & Comment \\
\hline $\begin{array}{l}\text { Tax } \\
\text { avoidance by } \\
\text { multinational } \\
\text { companies }\end{array}$ & $\$ 34.8 \mathrm{~b}$ & $\begin{array}{l}\text { The average revenue loss for countries in Africa as calculated } \\
\text { by Cobham/Jansky in recent research is } 2.19 \% \text { of GDP. }{ }^{95} \mathrm{Sub}- \\
\text { Saharan Africa's GDP was estimated at } \$ 1.59 \text { trillion in } 2015 .{ }^{96}\end{array}$ \\
\hline $\begin{array}{l}\text { Informal } \\
\text { sector }\end{array}$ & $\$ 49 b$ & $\begin{array}{l}\text { The average size of the informal sector across the five African } \\
\text { countries analysed is } 45.2 \% .{ }^{97} \text { Since sub-Saharan Africa's GDP is } \\
\text { estimated at } \$ 1.59 \text { trillion in } 201598 \text {, the informal sector may } \\
\text { amount to around } \$ 719 \text { billion. Lost tax revenues on this figure } \\
\text { may amount to around } \$ 97.2 \text { billion. } .{ }^{99} \text { However, many activities in } \\
\text { the informal economy are carried out by extremely poor people } \\
\text { who, it can be argued, should not be taxed. It is not possible to } \\
\text { provide a precise estimate of the legitimate proportion of this lost } \\
\text { income that should be gained by the state - we simply estimate } \\
\text { one half (thus } \$ 49 \text { billion) }\end{array}$ \\
\hline $\begin{array}{l}\text { Tax } \\
\text { incentives }\end{array}$ & $\$ 31.8 b$ & $\begin{array}{l}\text { Across the five African countries analysed, the average proportion } \\
\text { of GDP lost to tax incentives is } 2.9 \% \text {. However, this includes a } \\
\text { very high percentage for Tanzania ( } 8.9 \% \text { of GDP). We have } \\
\text { therefore chosen } 2.0 \% \text { of GDP as a more realistic average for } \\
\text { Africa. Given Sub-Saharan Africa's GDP as } \$ 1.59 \text { trillion in } \\
2015,100 \text { the revenue loss is } \$ 31.8 \text { billion. }\end{array}$ \\
\hline Corruption & $\$ 51.5 b$ & $\begin{array}{l}\text { Across the five African countries analysed, the average proportion } \\
\text { of GDP lost to corruption is } 3.24 \% \text { of GDP. }\end{array}$ \\
\hline $\begin{array}{l}\text { Debt } \\
\text { payments }\end{array}$ & $\$ 14.4 \mathrm{~b}$ & $\begin{array}{l}\text { The figure is for } 50 \% \text { of external debt service, by public and } \\
\text { private sectors, for sub-Saharan Africa in } 2015.101 \text { This is a rough } \\
\text { estimation of 'odious debts'; the figure of } 50 \% \text { is loosely based on }\end{array}$ \\
\hline
\end{tabular}




\begin{tabular}{|l|l|l|}
\hline & & $\begin{array}{l}\text { the estimation that some 60\% of external borrowing between } \\
1970-2004 \text { by Africa left the continent the same year in the form } \\
\text { of capital flight (Illicit Financial Flows). }{ }^{102}\end{array}$ \\
\hline TOTAL LOSS & $\mathbf{\$ 1 8 2 b}$ & \\
\hline $\begin{array}{l}\text { Revenue loss } \\
\text { per capita103 }\end{array}$ & $\mathbf{\$ 1 8 2}$ & \\
\hline
\end{tabular}

Aid

Sub-Saharan African countries received $\$ 42.8$ billion in aid in 2015.104

\section{What could the lost resources fund in health and education?}

Governments in sub-Saharan Africa allocated an average of $4.9 \%$ of their GDPs to education 105 and $5.5 \%$ to health. ${ }^{106}$ Together these expenditures come to around $10.5 \%$ of GDP. Thus lost revenues could double combined health and education spending in sub-Saharan Africa. 


\section{RECOMMENDATIONS}

\section{Low Income Country governments}

Low Income Countries should conduct a review of revenue losses from all potential revenue streams to see where leakages are occurring and to recommend actions to address them. Such processes must be transparently managed and involve civil society organisations.

\section{Developed country governments}

Developed country governments also need to review the various ways in which policies under their influence deprive low income countries of resources. In particular, they must take steps to stop illicit financial flows, require much higher levels of bank transparency, stop urging tax incentives for multinational companies and end unfair debt service payments. Aid should be used to support revenue authorities to build effective tax systems in low income countries. ${ }^{107}$

\section{Individuals}

We are all responsible for structural injustices and interact with these through the way we invest, consume and vote. Individuals committed to social justice should individually divest and collectively advocate for divestment from multinationals which engage in tax avoidance in low income countries. Many ethical investments avoid fossil fuels, tobacco and the arms industry, but we must also avoid depriving those living in low income countries the right to healthcare and an education.

\section{Illicit Financial Flows}

The international community and national governments should not tolerate the use of tax havens/secrecy jurisdictions by multinational companies. Governments could simply ban the use of tax havens by companies operating in their countries. Globally, much faster and deeper action is needed to achieve an international agreement to abolish tax havens. Multinational companies in all sectors must be required to report on their financial activities country-by-country.

Low Income Country governments, with financial support from the international community, need to significantly increase their capacity to monitor how multinational companies trade and price their goods, to ensure that trade misinvoicing and other schemes do not abuse countries.

\section{Informal sector}

Low Income Country governments must take far greater steps to broaden their tax bases by taxing all sectors and companies that should be taxed. National tax administrations need to be significantly built up, made more transparent and given 
greater powers, including with financial support from the international community.

\section{Tax incentives}

Low Income Country governments need to review the tax incentives they currently grant with a view or reducing or eliminating many of them, especially those given to corporations. Any tax incentives granted must be transparent, non-discretionary and time-limited.

\section{Government budget/corruption}

Low Income Country governments need to increase measures to ensure that public budgets are transparent and immune to corruption. National campaigns, stiffer penalties and greater monitoring are all needed. Civil society organisations can play a critical role in transparency and monitoring budgets at national, regional and local levels. In addition, some deeper structural problems need to be systematically addressed, such as low pay for civil servants.

\section{Debt payments}

Low Income Country governments should be paying back far less in debt service than they currently are: for example, lenders, such as donors, need to stop contributing to the debt crisis and provide aid as grants, not loans. There also needs to be greater transparency by making loan contracts publicly available and requiring parliamentary approval in the recipient country. 


\section{REFERENCES}

${ }^{1}$ GDP was MK 2,848 billion in 2014/15 (IMF, Malawi: Seventh and Eighth Reviews Under the Extended Credit Facility Arrangement, June 2016, p.23, http://www.imf.org/external/pubs/ft/scr/2016/cr16182.pdf). Exchange rate at 1 December 2015.

${ }^{2}$ Alex Cobham \& Petr Janský, 'Global distribution of revenue loss from tax avoidance: Re-estimation and country results', WIDER Working Paper, 2017, https://www.wider.unu.edu/publication/globaldistribution-revenue-loss-tax-avoidance, . Dataset used is available at: https://docs.google.com/spreadsheets/d/1r7jdXvQ1NaGjUUkH1afniE3xvTyCu7NC8BZWZjkkQk/edit\#gid=389779094

${ }^{3}$ Tax Justice Network, The Cost of Tax Abuse, 2011, April 2014, http://www.taxjustice.net/wpcontent/uploads/2014/04/Cost-of-Tax-Abuse-TJN-2011.pdf

${ }^{4}$ Malawi's GDP in 2014/15 was MK2,848 billion (IMF, Malawi: Seventh and Eighth Reviews Under the Extended Credit Facility Arrangement, June 2016, p.23,

http://www.imf.org/external/pubs/ft/scr/2016/cr16182.pdf) of which $41.8 \%$ is MK1,192b (\$2,307m) - if tax losses are calculated at the same rate as using the TJN formula for 2011, revenue losses amount to $\$ 380 \mathrm{~m}$.

${ }^{5}$ Cited in Dumbani Mzale, 'Government advised to review tax incentives', 10 February 2015, http://mwnation.com/government-advised-review-tax-incentives/

${ }^{6}$ Alexander Dzonzi, 'A Study of Malawi's Taxation Systems and Its Implications on the Poor', Draft report for the Malawi Economic Justice Network, December 2012, p.47

${ }^{7}$ The average exchange during 2008-12 has been around MK170/US\$

${ }^{8}$ World Bank, Ill-Gotten Money and the Economy: Experiences from Malawi and Namibia, 2011, Chapter 3 and 5 ,

https://books.google.es/books?id=Ns11SNcXcJIC\&pg=PT12\&lpg=PT12\&dq=malawi+informal+sector+t ax+losses\&source=bl\&ots=QdZgsSzcGS\&sig=gnJXBg9PS9R13fdh4GdMW_NQpqk\&hl=en\&sa=X\&ved =0ahUKEwjzrIjGxb7QAhXBORoKHQ6aDYAQ6AEIJDAB\#v=onepage $\& \mathrm{q}=$ malawi\%20informal\%20se ctor\%20tax\%20losses \&f=false

${ }^{9}$ IMF, Malawi: Seventh and Eighth Reviews Under the Extended Credit Facility Arrangement, June 2016, p.23, http://www.imf.org/external/pubs/ft/scr/2016/cr16182.pdf

${ }^{10}$ Exchange rate as at 1 December 2015.

${ }^{11}$ World Bank data at : http://data.worldbank.org/indicator/DT.INT.DPPG.CD

${ }^{12}$ James Boyce and Leonce Ndikumana, Africa's Odious Debts: How Foreign Loans and Capital Flight

Bled a Continent, 2011, http://africanarguments.org/africas-odious-debts/

${ }^{13}$ Based on population of $16.3 \mathrm{~m}$. ICTD figures at http://www.ictd.ac/datasets/the-ictd-governmentrevenue-dataset

${ }^{14}$ World Bank, Ill-Gotten Money and the Economy: Experiences from Malawi and Namibia, 2011, Chapter 3 and 5 ,

https://books.google.es/books?id=Ns11SNcXcJIC\&pg=PT12\&lpg=PT12\&dq=malawi+informal + sector $+\mathrm{t}$ ax+losses\&source=bl\&ots=QdZgsSzcGS\&sig=gnJXBg9PS9R13fdh4GdMW_NQpqk\&hl=en\&sa=X\&ved $=0$ ahUKEwjzrIjGxb7QAhXBORoKHQ6aDYAQ6AEIJDAB\#v=onepage \&q=malawi\%20informal\%20se ctor\%20tax\%20losses\&f=false

${ }^{15}$ Malawi's GDP in 2014/15 was MK 2,848 billion. Exchange rate as at 1 December 2015.IMF, Malawi: Seventh and Eighth Reviews Under the Extended Credit Facility Arrangement, June 2016, p.23, http://www.imf.org/external/pubs/ft/scr/2016/cr16182.pdf

16'World Bank: How Corruption And Tax Evasion Distort Development', 6 December 2011, https://financialtransparency.org/reports/world-bank-how-corruption-and-tax-evasion-distortdevelopment/

17'Aid (ODA) disbursements to countries and regions (DAC2a)', OECD Stat, http://stats.oecd.org/

18 2016/17 Budget Statement, para 60, http://www.finance.gov.mw/, accessed 23 November 2016

${ }^{19}$ MK723/\$ on 25 November 2016

${ }^{20}$ Alex Cobham \& Petr Janský, 'Global distribution of revenue loss from tax avoidance: Re-estimation and country results', WIDER Working Paper, 2017, https://www.wider.unu.edu/publication/globaldistribution-revenue-loss-tax-avoidance,. Dataset used is available at:

https://docs.google.com/spreadsheets/d/1r7jdXvQ1NaGjUUkH1afniE3xvTyCu7NC8BZWZjkkQk/edit\#gid=389779094

${ }^{21}$ Bruce Byiers, 'Informality in Mozambique: Characteristics, Performance and Policy Issues', USAID, 2009, p.6, http://www.speed-program.com/wp-content/uploads/2012/09/Informal-Sector-Study.pdf 
${ }^{22}$ Mozambique's GDP in 2015 was MT 598 billion (IMF, Staff Report for the 2015 Article IV

Consultation, January 2016, Table 4, http://www.imf.org/external/pubs/ft/scr/2016/cr1609.pdf) equivalent to $\$ 15.3$ billion (At the exchange rate of MT38.59/\$ prevailing on 1 July 2015). $40 \%$ of this amounts to $\$ 6.1$ billion. TJN figures used to calculate lost tax revenues on this figure are not available for

Mozambique as for the other countries, but the average tax loss for the other 4 African countries analysed in this report is $13.5 \%$, so we use this figure. $13.5 \%$ of $\$ 6.1$ billion is $\$ 824$ million.

${ }^{23}$ IMF, Republic of Mozambique: Selected Issues, 8 January 2016,

p.19,http://www.imf.org/external/pubs/ft/scr/2016/cr1610.pdf

${ }^{24}$ Based on nominal GDP of MT 482 billion / \$16.0 billion in 2013 and MT 532 billion / $\$ 17.0$ billion in 2014. IMF, Republic of Mozambique: Staff Report for the 2015 Article IV Consultation, January 2016, in two tables - both called Table 1 (because from different documents) on pages 30 and 11,

http://www.imf.org/external/pubs/ft/scr/2016/cr1609.pdf

${ }^{25}$ USAID, PARPA II Review - The Tax System in Mozambique, Vol.II, September 2009, Table E-1, http://www.open.ac.uk/technology/mozambique/sites/www.open.ac.uk.technology.mozambique/files/pics /d119379.pdf

${ }^{26}$ Tuan Minh Le, 'Measuring Efficiency and Productivity of Taxation: A

Review of Tax System in Mozambique', World Bank, 2016, p.10,

https://www.researchgate.net/publication/305042996_Measuring_Efficiency_and_Productivity_of_Taxati on_A_Review_of_Tax_System_in_Mozambique

${ }^{27}$ Based on Mozambique's GDP in 2015 of MT 598 billion, equivalent to $\$ 15.3$ billion at the exchange rate of MT38.59/\$ prevailing on 1 July 2015. IMF, Staff Report for the 2015 Article IV Consultation, January 2016, Table 4, http://www.imf.org/external/pubs/ft/scr/2016/cr1609.pdf

${ }^{28}$ Centro de Integridade Pública et al, Os Custos da Corrupção para a Economia Moçambicana: Por quê é que é importante combater a corrupção num clima de fragilidade fiscal, May 2016,

http://www.cip.org.mz/images/Documentos/Anti-Corrupcao/CIP-Custos_da_Corrupcao.pdf; 'Corruption costs 4\% of Mozambican GDP - Joseph Hanlon', 21 June 2016,

http://clubofmozambique.com/news/corruption-costs-4-of-mozambican-gdp-joseph-hanlon/; Centro de Integridade Pública, 'The Costs of Corruption to the Mozambican Economy', Policy Brief, 2016, http://cipmoz.org/images/Documentos/Sem_categoria/Policy_Brief_1_Eng.pdf

${ }^{29}$ IMF, Staff Report for the 2015 Article IV Consultation, January 2016, Table 4,

http://www.imf.org/external/pubs/ft/scr/2016/cr1609.pdf

${ }^{30}$ At the exchange rate of MT38.59/\$ prevailing on 1 July 2015

${ }^{31}$ Centro de Integridade Pública et al, Os Custos da Corrupção para a Economia Moçambicana: Por quê é que é importante combater a corrupção num clima de fragilidade fiscal, May 2016, p.13,

http://www.cip.org.mz/images/Documentos/Anti-Corrupcao/CIP-Custos_da_Corrupcao.pdf

${ }^{32}$ World Bank data at : http://data.worldbank.org/indicator/DT.INT.DPPG.CD

${ }^{33}$ James Boyce and Leonce Ndikumana, Africa's Odious Debts: How Foreign Loans and Capital Flight

Bled a Continent, 2011, http://africanarguments.org/africas-odious-debts/

${ }^{34}$ Based on population of $26.5 \mathrm{~m}$. ICTD figures at http://www.ictd.ac/datasets/the-ictd-governmentrevenue-dataset

35، Aid (ODA) disbursements to countries and regions (DAC2a)', OECD Stat, http://stats.oecd.org/

${ }^{36}$ In 2016, the government allocated MT54.4b (£1.2b) to education and MT $25.6 \mathrm{~b}(\$ 578 \mathrm{~m})$ to health

'Mozambique: Assembly Passes 2016 Plan and Budget', 16 December 2015,

http://allafrica.com/stories/201512161473.html. Using exchange rate of MT44.3/\$ on 1 December 2015

${ }^{37}$ Alex Cobham \& Petr Janský, 'Global distribution of revenue loss from tax avoidance: Re-estimation

and country results', WIDER Working Paper, 2017, https://www.wider.unu.edu/publication/global-

distribution-revenue-loss-tax-avoidance,. Dataset used is available at:

https://docs.google.com/spreadsheets/d/1r7jdXvQ1NaGjUUkH1afniE3xvTyCu7NC8BZWZjkkQk/edit\#gid=389779094

${ }^{38}$ Tax Justice Network, The Cost of Tax Abuse, 2011, April 2014, http://www.taxjustice.net/wp-

content/uploads/2014/04/Cost-of-Tax-Abuse-TJN-2011.pdf

${ }^{39}$ Nepal's GDP in 2016/17 was projected as Rs 2.73 trillion (\$25.2 billion). (IMF, 2015 Article IV

Consultation, unpaginated, http://www.imf.org/external/pubs/ft/scr/2015/cr15317.pdf). $36.7 \%$ of this is

Rs 1.0 trillion (\$9.3 billion). The Tax Justice Network estimated tax lost as $10.39 \%$ of the size of the shadow economy. Our figures are based on this.

${ }^{40}$ In April 2015 the Director General of Nepal's Inland Revenue Department said that a 'very rough estimation of revenue foregone [from tax incentives] is approximately 5\% of GDP' (Chudamani Sharma, 'Tax Incentives in Nepal: An Overview', 7 April 2015,

https://www.imf.org/external/np/seminars/eng/2015/asiatax/pdf/sharma.pdf). 
${ }^{41}$ The figure cited compares to reports from Nepal's Auditor General, which state that Nepal lost revenues amounting to Rs 45.8 billion in 2013/14 and Rs 31.4 billion in 2012/13 (Office of the Auditor General, Fifty-Second (52nd) Annual Report of the Auditor General 2071 (2015), Summary, April 2015, para 42, http://www.oagnep.gov.np/downloadfile/Executive\%20Summary\%20English\%202071_1441617260.pdf; Office of the Auditor General, Fifty-first (51st) Annual Report of the Auditor General 2070 (2014),

Summary, para 50, April 2014, http://www.oagnep.gov.np/downloadfile/Final\%20-

\%20Summary\%20of\%20the\%200AG\%20Report\%202070\%20English\%2027062014_1403946212.pdf)

Using middle-of-the-year exchange rates, these convert to \$462 million in 2013/14 and \$357 million in 2012/13.

${ }^{42}$ Transparency International Nepal, A Survey on Public Service Delivery 2016,

https://issuu.com/tinepal/docs/a_survey_on_public_service_delivery

${ }^{43} \mathrm{U} 4$, Corruption and governance indicators in selected Asian countries, 2016, file:///C:/Users/PC/AppData/Local/Temp/476-2016-03.pdf

${ }^{44}$ World Bank data at : http://data.worldbank.org/indicator/DT.INT.DPPG.CD

${ }^{45}$ James Boyce and Leonce Ndikumana, Africa's Odious Debts: How Foreign Loans and Capital Flight

Bled a Continent, 2011, http://africanarguments.org/africas-odious-debts/

${ }^{46}$ Based on population of $27.8 \mathrm{~m}$. ICTD figures at http://www.ictd.ac/datasets/the-ictd-governmentrevenue-dataset

47، Aid (ODA) disbursements to countries and regions (DAC2a)',OECD Stat, http://stats.oecd.org/

${ }^{48}$ Budget Speech, Fiscal year 2016/17, Annex 5,

http://mof.gov.np/uploads/document/file/Budget_Speech_final_2016_20160602105902.pdf

${ }^{49}$ Alex Cobham \& Petr Janský, 'Global distribution of revenue loss from tax avoidance: Re-estimation and country results', WIDER Working Paper, 2017, https://www.wider.unu.edu/publication/globaldistribution-revenue-loss-tax-avoidance,. Dataset used is available at:

https://docs.google.com/spreadsheets/d/1r7jdXvQ1NaGjUUkH1afniE3xvTyCu7NC8BZWZjkkQk/edit\#gid=389779094

${ }^{50}$ Tax Justice Network, The Cost of Tax Abuse, 2011, April 2014, http://www.taxjustice.net/wpcontent/uploads/2014/04/Cost-of-Tax-Abuse-TJN-2011.pdf

${ }^{51}$ Sierra Leone's GDP was Le 26.7 trillion (\$4.1 billion) in 2016/17 (IMF, Sixth Review under the Extended Credit Facility Arrangement, December 2016, pp.24, 31,

$\mathrm{http}: / / \mathrm{www}$.imf.org/external/pubs/ft/scr/2016/cr16378.pdf) of which $45.6 \%$ is Le 12.2 trillion. If tax losses are calculated at the same rate as using the TJN formula for 2011, revenue losses amount to Le 1.3 trillion $(\$ 175 \mathrm{~m})$

${ }^{52}$ IMF, 2016 Article IV Consultation, July 2016, pp.12, 63,

https://www.imf.org/external/pubs/ft/scr/2016/cr16236.pdf

${ }^{53}$ See Budget Advocacy Network et al, Losing Out: Sierra Leone's Massive Revenue Losses from Tax Incentives, 2014, http://curtisresearch.org/wp-content/uploads/Losing-Out.-Final-report.-April-2014.pdf ${ }^{54} \mathrm{U} 4$, Overview of corruption and anti-corruption in Sierra Leone, 2010, p.3,

http://www.u4.no/publications/overview-of-corruption-and-anti-corruption-in-sierra-leone/

55 The government's total expenditure was le 4.6 trillion in 2016 of which $10 \%$ is Le 460 billion $(\$ 62 \mathrm{~m})$. Citizens' Budget 2016, p.23, http://mofed.gov.s//PUBLICATIONS/2016\%20Citizens\%20Budget.pdf

${ }^{56}$ World Bank data at : http://data.worldbank.org/indicator/DT.INT.DPPG.CD

${ }^{57}$ James Boyce and Leonce Ndikumana, Africa's Odious Debts: How Foreign Loans and Capital Flight Bled a Continent, 2011, http://africanarguments.org/africas-odious-debts/

${ }^{58}$ Figure of at the midpoint between $\$ 233 \mathrm{~m}$ and $\$ 303 \mathrm{~m}$. Based on population of $6.2 \mathrm{~m}$. ICTD figures at http://www.ictd.ac/datasets/the-ictd-government-revenue-dataset

${ }^{59}$ IMF, Sixth Review under the Extended Credit Facility Arrangement, December 2016, p.4, http://www.imf.org/external/pubs/ft/scr/2016/cr16378.pdf

${ }^{60}$ IMF, Sixth Review under the Extended Credit Facility Arrangement, December 2016, p.24, http://www.imf.org/external/pubs/ft/scr/2016/cr16378.pdf

${ }^{61}$ 'Aid (ODA) disbursements to countries and regions (DAC2a)',OECD Stat, http://stats.oecd.org/

${ }^{62}$ Government Budget and Statement of Economic Financial Policies, 2017, November 2016, Tables 3a and $5 b$,

http://www.parliament.gov.sl/dnn5/Portals/0/2014\%20DOCUMENT/BUDGET/2017\%20Budget\%20Spe ech\%20and\%20Profile.pdf

${ }^{63}$ Alex Cobham \& Petr Janský, 'Global distribution of revenue loss from tax avoidance: Re-estimation and country results', WIDER Working Paper, 2017, https://www.wider.unu.edu/publication/globaldistribution-revenue-loss-tax-avoidance,. Dataset used is available at:

https://docs.google.com/spreadsheets/d/1r7jdXvQ1NaGjUUkH1afniE3xvTyCu7NC8BZWZjkkQ- 
k/edit\#gid=389779094

${ }^{64}$ Tax Justice Network, The Cost of Tax Abuse, 2011, April 2014, http://www.taxjustice.net/wpcontent/uploads/2014/04/Cost-of-Tax-Abuse-TJN-2011.pdf

${ }^{65}$ In 2016/17, Tanzania's GDP was projected as $\$ 48.3$ billion (TShs 109 trillion) (IMF, Staff Report for the 2016 Article IV Consultation, p.15, July 2016,

http://www.imf.org/external/pubs/ft/scr/2016/cr16253.pdf) of which 56.4\% is $\$ 27.3$ billion (Shs 62 trillion). If tax losses are calculated at the same rate as using the TJN formula for 2011, revenue losses amount to $\$ 4.04$ billion or Shs (Shs 9.2 trillion)

${ }^{66}$ Another estimate comes from the Economic and Social Research Foundation (ESRF), such that the revenue lost from not taxing the informal sector amounts to $35-55 \%$ of the total tax revenue. (ESRF, 'Informal Sector Taxation in Tanzania', TAKNET Policy Brief, 2010,

http://www.taknet.or.tz/topics/informationsectortaxationintanzania_12.pdf) . Using the government's tax collection projection of Shs 15.1 trillion in 2016/17, if 35-55\% of this collection is lost to the informal sector and the government could realistically collect one half of this, this would amount to an extra TShs 3.4 trillion $(\$ 1.5 b)$.

67 'Exemptions and Relief From July 2015 To June 2016',

http://www.mof.go.tz/mofdocs/exemptions/Exemptions\%20and\%20Relief_From_JULY-

2015_TO_JUNE-2016.pdf

${ }^{68}$ At exchange prevailing at 1 December 2015 , ie, TShs 2,162/\$1

${ }^{69}$ Bertelsmann Foundation, Tanzania Country Report, 2016, p.11, https://www.bti-

project.org/fileadmin/files/BTI/Downloads/Reports/2016/pdf/BTI_2016_Tanzania.pdf; U4, 'Tanzania:

Overview of Corruption and Anti-Corruption', p.3, http://www.u4.no/publications/tanzania-overview-ofcorruption-and-anti-corruption/

${ }^{70}$ Citizens' Budget 2016/17, p.10,

http://www.mof.go.tz/mofdocs/budget/Citizens\%20Budget/CITIZENS\%20BUDGET\%2016-

$17 \% 20 \% 20 \% 20$ (English).pdf

${ }^{71}$ World Bank data at : http://data.worldbank.org/indicator/DT.INT.DPPG.CD

${ }^{72}$ James Boyce and Leonce Ndikumana, Africa's Odious Debts: How Foreign Loans and Capital Flight

Bled a Continent, 2011, http://africanarguments.org/africas-odious-debts/

${ }^{73}$ Based on population of $50.2 \mathrm{~m}$. ICTD figures at http://www.ictd.ac/datasets/the-ictd-governmentrevenue-dataset

${ }^{74}$ IMF, Staff Report for the 2016 Article IV Consultation, p.13, July 2016,

http://www.imf.org/external/pubs/ft/scr/2016/cr16253.pdf; IMF, Tanzania: Selected Issues, July 2016,

p.25, http://www.imf.org/external/pubs/ft/scr/2016/cr16254.pdf. The IMF actually gives two figures -

$2.2 \%$ and $2.8 \%$

${ }^{75}$ IMF, Tanzania: Selected Issues, July 2016, p.27,

http://www.imf.org/external/pubs/ft/scr/2016/cr16254.pdf

${ }^{76}$ In 2016/17, Tanzania's GDP was projected as $\$ 48.3$ billion (TShs 109 trillion). Figures calculated at

2.5\%. IMF, Staff Report for the 2016 Article IV Consultation, p.15, July 2016,

http://www.imf.org/external/pubs/ft/scr/2016/cr16253.pdf

${ }^{77}$ 'Aid (ODA) disbursements to countries and regions (DAC2a)',OECD Stat, http://stats.oecd.org/

${ }^{78}$ Citizens' Budget 2016/17, pp.11, 13

http://www.mof.go.tz/mofdocs/budget/Citizens\%20Budget/CITIZENS\%20BUDGET\%2016-

$17 \% 20 \% 20 \% 20$ (English).pdf

${ }^{79}$ Alex Cobham \& Petr Janský, 'Global distribution of revenue loss from tax avoidance: Re-estimation

and country results', WIDER Working Paper, 2017, https://www.wider.unu.edu/publication/global-

distribution-revenue-loss-tax-avoidance,. Dataset used is available at:

https://docs.google.com/spreadsheets/d/1r7jdXvQ1NaGjUUkH1afniE3xvTyCu7NC8BZWZjkkQ-

k/edit\#gid=389779094

${ }^{80}$ Tax Justice Network, The Cost of Tax Abuse, 2011, April 2014, http://www.taxjustice.net/wp-

content/uploads/2014/04/Cost-of-Tax-Abuse-TJN-2011.pdf

${ }^{81}$ Uganda's GDP was estimated at UShs 84.9 trillion (\$24.7 billion) in 2015/16 (IMF, Seventh Review Under the Policy Support Instrument, January 2017, p.20,

http://www.imf.org/external/pubs/ft/scr/2017/cr1707.pdf) of which $42.3 \%$ is UShs 36.0 trillion ( $\$ 10.5$ billion). If tax losses are calculated at the same rate as using the TJN formula for 2011, revenue losses amount to UShs 4.3 trillion ( $\$ 1.25$ billion)

${ }^{82}$ Uganda's GDP was estimated at UShs 84.9 trillion (\$24.7 billion) in 2015/16. IMF, Seventh Review

Under the Policy Support Instrument, January 2017, p.20,

http://www.imf.org/external/pubs/ft/scr/2017/cr1707.pdf 
${ }^{83}$ African Development Bank, Domestic Resource Mobilisation for Poverty Reduction in East Africa: Uganda Case Study, November 2010, p.20,

https://www.afdb.org/fileadmin/uploads/afdb/Documents/Project-and-

Operations/Uganda\%20case\%20study\%20final.pdf

${ }^{84}$ Based on figures in IMF, Uganda: Second Review under the Policy Support Instrument and Request for Waiver of Assessment Criteria, Country Report No.11, October 2011, p.24. Nominal GDP in 2009/10 of UShs 34.5 trillion

${ }^{85}$ At the exchange rate of UShs 2,300/\$ prevailing in December 2010

${ }^{86}$ Cited in Stephen Wandera, 'Review tax exemptions, MPs tell government', 9 July 2013, http://www.monitor.co.ug/News/National/Review-tax-exemptions--MPs-tell-government//688334/1909072/-/121x2st/-/index.html

${ }^{87}$ ActionAid, Still Racing Toward The Bottom? Corporate Tax Incentives in East Africa, June 2016, $\mathrm{http}: / /$ curtisresearch.org/publications/still-racing-toward-the-bottom-corporate-tax-incentives-in-eastafrica/

${ }^{88} \mathrm{U} 4$, Overview of corruption and anti-corruption in Uganda, 2013, p.2,

http://www.u4.no/publications/uganda-overview-of-corruption-and-anti-corruption/

89 'Probe reveals new ways of stealing money from government', 23 July 2016,

http://mobile.monitor.co.ug/News/Probe-reveals-new-ways-stealing-money-government/2466686-

3306672-format-xhtml-cvxkd/index.html

${ }^{90}$ World Bank data at : http://data.worldbank.org/indicator/DT.INT.DPPG.CD

${ }^{91}$ James Boyce and Leonce Ndikumana, Africa's Odious Debts: How Foreign Loans and Capital Flight

Bled a Continent, 2011, http://africanarguments.org/africas-odious-debts/

${ }^{92}$ Based on population of $36.6 \mathrm{~m}$. ICTD figures at http://www.ictd.ac/datasets/the-ictd-governmentrevenue-dataset

93، Aid (ODA) disbursements to countries and regions (DAC2a)', OECD Stat, http://stats.oecd.org/

${ }^{94}$ Budget Speech Financial Year 2016/17, Annex

4,https://www.mediacentre.go.ug/sites/default/files/rescrc/Speech\%202016.pdf

${ }^{95}$ Alex Cobham \& Petr Janský, 'Global distribution of revenue loss from tax avoidance: Re-estimation and country results', WIDER Working Paper, 2017, https://www.wider.unu.edu/publication/globaldistribution-revenue-loss-tax-avoidance,. Dataset used is available at:

https://docs.google.com/spreadsheets/d/1r7jdXvQ1NaGjUUkH1afniE3xvTyCu7NC8BZWZjkkQk/edit\#gid=389779094

${ }^{96}$ World Bank data, http://data.worldbank.org/region/sub-saharan-africa

${ }^{97}$ Using figures in Tax Justice Network, The Cost of Tax Abuse, 2011, April 2014, http://www.taxjustice.net/wp-content/uploads/2014/04/Cost-of-Tax-Abuse-TJN-2011.pdf

${ }^{98}$ World Bank data, http://data.worldbank.org/region/sub-saharan-africa

${ }^{99}$ Using figures provided by Tax Justice Network, the average tax loss on the informal sector was $13.5 \%$ across the four African countries analysed for which TJN provided data. Tax Justice Network, The Cost of Tax Abuse, 2011, April 2014, http://www.taxjustice.net/wp-content/uploads/2014/04/Cost-of-Tax-

Abuse-TJN-2011.pdf

${ }^{100}$ World Bank data, http://data.worldbank.org/region/sub-saharan-africa

${ }^{101}$ World Bank, World Development Indicators database,

http://databank.worldbank.org/data/reports.aspx?source=international-debt-statistics

${ }^{102}$ James Boyce and Leonce Ndikumana, Africa's Odious Debts: How Foreign Loans and Capital Flight

Bled a Continent, 2011, http://africanarguments.org/africas-odious-debts/

${ }^{103}$ Population of 1.0 billion. http://data.worldbank.org/region/sub-saharan-africa

104، Aid (ODA) disbursements to countries and regions (DAC2a)', OECD Stat, http://stats.oecd.org/

${ }^{105}$ Using latest available figures for countries at Unesco, http://data.uis.unesco.org/?queryid=181

${ }^{106}$ World Bank data at http://data.worldbank.org/indicator/SH.XPD.TOTL.ZS?locations=ZG

${ }^{107}$ Odd-Helge Fjeldstad, 'Tax and development: Donor support to strengthen tax systems in developing countries', August 2014, http://onlinelibrary.wiley.com/doi/10.1002/pad.1676/abstract 